DOI: 10.19195/2300-7729.35.4

\title{
Wpływ systemu POL-on na dokumentowanie dorobku naukowego pracowników uczelni wyższych
}

W artykule zostały omówione najważniejsze założenia systemu POL-on oraz jego wpływ na dokumentowanie dorobku naukowego realizowanego przez biblioteki. Podjęto próbę analizy i oceny dotychczasowych doświadczeń przy realizacji tego zadania. Niniejszy tekst jest głosem w toczącej się dyskusji i próbą odpowiedzi na trudne pytania:

— w jakim zakresie wprowadzony system spełnia oczekiwania środowiska naukowego?

— jakie zmiany w bibliotekach i uczelniach wymusił lub rozwiązał system POL-on?

— czy obowiązki sprawozdawania danych o publikacjach wpłynęły na efekty współpracy biblioteki z jednostkami naukowymi?

\section{Idea i zasady funkcjonowania}

W 2015 r. wraz z wejściem w życie znowelizowanej ustawy o zasadach finansowania nauki uczelnie wyższe, w tym biblioteki, otrzymały wiele nowych obowiązków sprawozdawczych, a wraz z nimi pojawiły się nowe wyzwania. Wprowadzona 15 stycznia 2015 r. ustawa o zasadach finansowania nauki ${ }^{1}$ zobligowała wszystkie jednostki naukowe w kraju do wprowadzania danych o działalności naukowej, badawczo-rozwojowej, w tym informacji o publikacjach. Wprowadzony został System Informacji o Nauce w ramach Zintegrowanego Systemu Infor-

${ }^{1}$ Ustawa z dnia 15 stycznia 2015 r. o zmianie ustawy o zasadach finansowania nauki oraz niektórych innych ustaw nauki., Dz.U. 2015, poz. 249, http://www.dziennikustaw.gov.pl/DU/2015/249/1 [dostęp: 10.07.2016]. 
macji o Szkolnictwie Wyższym POL-on, który będzie gromadził szczegółowe dane o polskich uczelniach i nauce.

Najważniejsze cele i zadania zintegrowanego systemu to:

— wspieranie pracy Ministerstwa Nauki i Szkolnictwa Wyższego,

— wykorzystanie danych przez Główny Urząd Statystyczny,

— utworzenie bazy danych dla Centralnej Komisji do Spraw Stopni i Tytułów,

— utworzenie jednolitego źródła informacji/bazy danych o jednostkach naukowych, wyższych uczelniach i nauce polskiej.

Główne założenia i zalety zintegrowanego systemu informacji o polskich uczelniach i polskiej nauce POL-on to:

- gromadzenie danych o wszystkich polskich jednostkach naukowych, do których publiczny dostęp wynika z ustaw i rozporządzeń MNiSW,

— jednolity sposób gromadzenia, przechowywania i udostępniania informacji o szkolnictwie wyższym w Polsce,

- baza sprawozdawczo-informacyjna, która będzie podstawą oceny parametrycznej jednostek naukowych w kraju,

- nowoczesne zarządzanie nauką,

— narzędzie wspomagające podział dotacji statutowej,

— wspieranie infrastruktury badawczej,

— wzmocnienie aktywności polskich naukowców w Europejskiej Przestrzeni Badawczej².

Wartość gromadzonych w systemie danych, cyklicznie sprawozdawanych bezpośrednio przez same jednostki, będzie wiarygodna i bardzo cenna. $Z$ tego powodu system POL-on został wskazany przez ministra nauki i szkolnictwa wyższego jako oficjalny system parametryzacji oraz sprawozdawczości uczelni wyższych.

System POL-on składa się z 21 modułów, które wyodrębniono na podstawie obszarów tematycznych ${ }^{3}$.

Jednym z elementów systemu POL-on jest Polska Bibliografia Naukowa (PBN), w której funkcjonują moduły: repozytoryjny i sprawozdawczy. Do modułu sprawozdawczego przesyłane są cyklicznie sprawozdania z działalności publikacyjnej uczelni wyższych.

Ideą powstania PBN była potrzeba gromadzenia i prowadzenia w skali kraju informacji o polskich i zagranicznych czasopismach naukowych oraz publikacjach polskich naukowców. Jak napisano na stronie PBN: „Polska Bibliografia Naukowa umożliwia:

— stworzenie publicznej bibliografii naukowej osób i instytucji,

— zapoznanie się z dorobkiem polskich naukowców,

${ }^{2}$ O systemie. POL-on. Zintegrowany System o Nauce i Szkolnictwie Wyższym, https://polon. nauka.gov.pl/system [dostęp: 12.07.2016].

${ }^{3}$ Funkcjonalności wdrożone. POL-on. Zintegrowany System o Nauce i Szkolnictwie Wyższym, https://polon.nauka.gov.pl/funkcjonalnosci-wdrozone1 [dostęp: 10.07.2016]. 
— zapoznanie się z dorobkiem polskich instytucji naukowych,

— złożenie ankiety czasopisma naukowego (w czasie cyklicznych ewaluacji czasopism naukowych),

- deponowanie pełnych tekstów publikacji w centralnym repozytorium PBN.

W przyszłości portal PBN wzbogacony zostanie o inne funkcje, takie jak:

— integracja z zasobami repozytoriów instytucjonalnych polskich uczelni i jednostek naukowych,

— formatowanie bibliografii osób i instytucji w sposób wymagany przez inne podmioty"4.

Rozporządzenie Ministra Nauki i Szkolnictwa Wyższego z dnia 29 czerwca 2015 r. w sprawie Systemu Informacji o Nauce zaczęło obowiązywać od 3 lipca 2015 r.

Załącznik nr 1 do rozporządzenia zawierał szczegółowy zakres danych i informacji, które należy sprawozdawać, terminy ich aktualizacji oraz formę udostępniania tych informacji ${ }^{5}$. Zgodnie $\mathrm{z}$ rozporządzeniem jednostki naukowe zobligowane zostały do wprowadzenia danych o publikacjach za lata 2013-2015 w terminie do 25 sierpnia $2015 \mathrm{r}$.

Zadanie trudne do wykonania ze względu na:

— zbyt krótki czas na realizację,

- duży zakres danych,

— nowe elementy opisu bibliograficznego, dotychczas niegromadzone w bibliotekach i jednostkach naukowych.

Nowy zakres obowiązków wymagał proceduralnego i merytorycznego przygotowania się do zadania. W uczelniach dopiero po ukazaniu się rozporządzenia można było rozpocząć proces tworzenia zasad, wdrażania narzędzi i wyznaczania osób odpowiedzialnych za:

- gromadzenie,

- uzupełnianie,

- merytoryczną ocenę publikacji i ich kwalifikację,

- dostosowanie danych do formatów określonych przez MNiSW,

- terminowy import danych.

Zastanawiano się, komu nadać uprawnienia importera publikacji i przypisać odpowiedzialność za wprowadzanie i przesyłanie danych o publikacjach do modułu sprawozdawczego. Uczelnie przyjęły w tym zakresie różne rozwiązania.

W wielu uczelniach zadania te powierzono bibliotekom. W niektórych uczelniach ten obowiązek przejęły (zgodnie z zapisami ustawy) jednostki naukowe. Do-

${ }^{4}$ O nas. PBN. Polska Bibliografia Naukowa, https://pbn-test.opi.org.pl/sedno-webapp/ [dostęp: 10.07.2016].

${ }^{5}$ Rozporządzenie Ministra Nauki i Szkolnictwa Wyższego z dnia 29 czerwca 2015 r. w sprawie Systemu Informacji o Nauce, Dz.U. 2015, poz. 944, http://isap.sejm.gov.pl/DetailsServlet?id=WDU20150000944 [dostęp: 10.07.2016]. 
stęp do modułu sprawozdawczego PBN otrzymały tylko upoważnione osoby potwierdzone przez operatora PBN. Powierzono im funkcje importerów publikacji.

W związku z tym, że zadania nałożone na jednostki naukowe przypisane zostały niefortunnie na czas wakacji, a dotyczyły obszernego zakresu danych, które należało uzupełnić, w dniu 10 lipca 2015 r. MNiSW wydało komunikat skierowany do rektorów uczelni wyższych w sprawie terminu wprowadzenia danych i informacji do Systemu Informacji o Nauce ${ }^{6}$. Zgodnie z nim termin sprawozdawania danych został przesunięty na październik $2015 \mathrm{r}$.

W nawiązaniu do wydanego komunikatu na stronie PBN ukazała się informacja o czasowym wstrzymaniu importu masowego z jednostek do systemu.

Powodów było kilka:

— system został wdrożony zbyt szybko,

- bez konsultacji środowiska naukowego i testów,

- wymaga modyfikacji i dostosowania do obowiązujących aktów prawnych.

Dopiero uruchomiony 7 sierpnia 2015 r. w ramach PBN moduł sprawozdawczy umożliwił jednostkom naukowym wywiązanie się z obowiązku wprowadzania danych sprawozdawczych, które wynikają z rozporządzenia ministra? ${ }^{7}$.

Moduł repozytoryjny to ogólnodostępna baza rejestrująca dorobek pracowników jednostek naukowych. Każdy może tam wprowadzać samodzielnie swoje publikacje, wyszukiwać informacje o nich, edytować je.

Utworzenie modułu sprawozdawczego dało jednostkom czas na wprowadzenie danych do 30 października 2015 r. Wprowadzenie danych do modułu sprawozdawczego PBN było możliwe za pomocą importu masowego lub ręcznego dodawania publikacji. Importu danych w imieniu jednostki naukowej dokonują osoby z przydzielonymi uprawnieniami importera publikacji. Upoważniony importer publikacji może: zarządzać swoim kontem, zmieniać lub generować nowe hasło, wprowadzać publikacje do bazy PBN, dokonać masowego importu do modułu sprawozdawczego, przeglądać raporty importów, edytować, usuwać i przeglądać zaimportowane dane.

\section{Biblioteki wobec nowych zadań}

Praktyczna strona wywiązywania się z nałożonych obowiązków była skomplikowana i trudna do realizacji. Moduł sprawozdawczy PBN służy do masowego importu danych w ściśle określonym przez realizatorów projektu formacie.

\footnotetext{
${ }^{6}$ Komunikat w sprawie terminu wprowadzenia danych i informacji do systemu informacji o nauce w ramach Zintegrowanego Systemu Informacji o Nauce i Szkolnictwie Wyższym POL-on, http:// www.nauka.gov.pl/g2/oryginal/2015_07/cdlbbba140db3271185d573b1009ec42.pdf [dostęp: 10.07.2016].

${ }^{7}$ Rozporządzenie Ministra Nauki i Szkolnictwa Wyższego z dnia 13 lipca 2012 r. w sprawie kryteriów i trybu wyznaczania kategorii naukowej jednostkom naukowym, Dz.U. 2012, poz. 877, http://isap.sejm.gov.pl/DetailsServlet?id=WDU20120000877 [dostęp: 10.07.2016].
} 
Szczegółowe dane bibliograficzne zawarte w rozporządzeniu nie były gromadzone w bibliotecznych bazach publikacji pracowników.

Należą do nich:

- nazwa konferencji (pełna i skrócona),

- data rozpoczęcia i zakończenia konferencji,

— kod języka,

— kod państwa,

— objętość publikacji w arkuszach wydawniczych,

- identyfikator DOI czasopisma i artykułu,

— informacja o indeksowaniu publikacji w bazach czasopism i abstraktów Web of Science Core Collection,

— informacja o otwartym dostępie i rodzaju licencji, na podstawie której publikacja jest udostępniana.

$\mathrm{W}$ celu ich uzupełnienia potrzebny był kontakt $\mathrm{z}$ autorem publikacji lub czasochłonne poszukiwania, a także ponowne przeglądanie wielu rekordów.

Operatorem PBN w pierwszym etapie jej funkcjonowania w zakresie utrzymania systemu, zapewnienia pomocy użytkownikom, dostosowania do zmian prawnych była firma Index Copernicus International. Jest ona również twórcą Systemu Ewaluacji Dorobku Naukowego, za pomocą którego przeprowadzano w kraju ewaluację jednostek naukowych oraz ocenę czasopism naukowych. Ze względu na fakt, że z modułu sprawozdawczego od 65\% do $80 \%$ danych o publikacjach będzie miało wpływ na sposób przyznawania środków statutowych, ocenę parametryczną jednostek oraz ich kategoryzację, ważne jest, aby kwestiom gromadzenia kompletnych informacji na uczelniach nadać priorytet, wskazać rangę i znaczenie wprowadzania rzetelnych i kompletnych informacji.

Ustawodawca wyznaczył kwartalne terminy przesyłania sprawozdań do systemu POL-on (do 31 października 2015 r. i do 31 stycznia 2016 r.) określonych w rozporządzeniu typów publikacji:

— artykuły w czasopismach naukowych,

- monografie naukowe,

- rozdziały w monografiach naukowych.

Moduł sprawozdawczy nie jest ukończony, wciąż jest rozwijany, pojawiają się nowe funkcje, nie zawsze działające właściwie. Brakuje informacji o wprowadzonych zmianach, nowych funkcjach, nie ma właściwie działającego systemu pomocy ze strony firmy obsługującej system. PBN w przyszłości ma pełnić funkcję krajowego repozytorium publikacji naukowych, którego zawartość będą stanowiły zwalidowane dane o publikacjach polskich naukowców wspierające Komisję Ewaluacji Jednostek Naukowych w procesie oceny jednostek, zgodnie z rozporządzeniem w sprawie kryteriów i trybu wyznaczania kategorii naukowej jednostek naukowych ${ }^{8}$. MNiSW przygotowuje nowelizację rozporządzenia. Za-

\footnotetext{
${ }^{8}$ Ibidem.
} 
kończyły się konsultacje społeczne w sprawie projektu rozporządzenia, jednostki naukowe $\mathrm{z}$ niecierpliwością i niepokojem czekają na wprowadzenie zapisów zmian, zastanawiając się, w jakim stopniu wpłyną na zbliżającą się ich ocenę parametryczną. Czy ta kolejna zmiana dotyczyć będzie również procesu i sposobu sprawozdawania danych przez biblioteki? Tego nie wiemy.

Mimo licznych problemów: czasowych, osobowych, mało precyzyjnych zapisów, zmieniających się rozporządzeń i przesyłanych komunikatów biblioteki i jednostki naukowe z ogromnym wysiłkiem i zaangażowaniem starały się wywiązać z nałożonych obowiązków we wskazanych terminach.

\section{Bibliograficzne bazy a sprawozdawanie danych do POL-on}

Gdy jednostki naukowe w kraju przygotowywały się do kolejnego okresu sprawozdawczego, nieoczekiwanie wydane zostało nowe Rozporządzenie Ministra Nauki i Szkolnictwa Wyższego z dnia 26 lutego 2016 r. zmieniające Rozporządzenie w sprawie Systemu Informacji o Nauce (Dz.U. 2016, poz. 309), które weszło w życie 26 marca 2016 r. Rozporządzenie dotyczyło zmiany terminów aktualizowania informacji w systemie POL-on. Uczelnie otrzymały informacje, że m.in. dane dotyczące publikacji w czasopismach naukowych oraz monografiach naukowych lub w rozdziałach w monografiach naukowych pracowników jednostki naukowej oraz publikacji osób niebędących pracownikami jednostki, które afiliowały te publikacje do tej jednostki, będą aktualizowane dwa razy w roku według stanu na dzień:

- 30 czerwca (dane należy przesyłać w terminie do końca sierpnia danego roku), roku) $)^{9}$.

31 grudnia (dane należy przesyłać terminie do końca lutego następnego

Wraz ze zmianą terminów poinformowano również o zmianie operatora systemu POL-on, którym został Ośrodek Przetwarzania Informacji (OPI).

Jednostki naukowe w kraju otrzymały informację o zawieszeniu funkcjonowania systemu do czasu wprowadzenia modyfikacji oraz dostosowania go do oczekiwań środowiska akademickiego. Po raz kolejny, bez wcześniejszego uprzedzenia, wprowadzono zmianę zasad w trakcie funkcjonowania systemu. Brak szczegółowych informacji spowodował dezinformację i niepokój wśród osób odpowiedzialnych za sprawozdawanie danych w ustawowym terminie. Nowe zasady sprawozdawania danych przekazano dopiero na zorganizowanych przez OPI

${ }^{9}$ Rozporządzenie Ministra Nauki i Szkolnictwa Wyższego z dnia 26 lutego 2016 r. zmieniające rozporządzenie w sprawie Systemu Informacji o Nauce, Dz.U. 2016, poz. 309, http://dziennikustaw.gov.pl/du/2016/309/1 [dostęp: 10.07.2016]. 
w Warszawie w dniach 28-29 czerwca 2016 r. szkoleniach pt. „Techniczne aspekty wprowadzania danych do nowego modułu sprawozdawczego PBN".

Na stronie PBN nowy operator OPI umieścił informacje o planowanym udostępnieniu wersji produkcyjnej obu aplikacji: dotychczasowej i nowej. Poinformowano, że w nadchodzącym okresie sprawozdawczym będzie można pracować zarówno na dotychczasowej, jak i nowej aplikacji. Obie będą pracowały na tej samej bazie danych, więc bez względu na to, z której użytkownik skorzysta, będzie miał dostęp do tych samych danych.

W nowej aplikacji operator zaprezentował alternatywne rozwiązania w module sprawozdawczym. Są one znacznie nowocześniejsze oraz umożliwiają dalszy rozwój systemu zarówno pod kątem ergonomii pracy, jak i intuicyjności poszczególnych elementów.

Obecne środowisko produkcyjne składa się z trzech aplikacji:

1. dotychczasowej aplikacji PBN, rozszerzonej o nowe funkcje,

2. dotychczasowej aplikacji POL-index,

3. nowej aplikacji sprawozdawczej.

Spełniając oczekiwania użytkowników z jednostek naukowych, nowy operator stworzył środowisko testów zewnętrznych, które miały umożliwić sprawdzenie całego procesu sprawozdawczego, by pomóc udoskonalić aplikację.

Nowa aplikacja pozwoli dopełnić proces sprawozdawczy bez tworzenia formalnego sprawozdania oraz jego zamykania ${ }^{10}$.

Kolejne wprowadzone zmiany $\mathrm{w}$ dotychczasowym module sprawozdawczym (PBN-S) dotyczą możliwości przeglądu prac zaimportowanych z modułu repozytoryjnego (PBN-R), utworzenia statystyki wysłanych publikacji i innych.

Do czasu oceny parametrycznej jednostek naukowych będzie utrzymywana dualność aplikacji klasycznej i nowej, tzw. PBN klasyczny i PBN nowy.

Jednostkom naukowym udostępnione zostaną wersje testowe ankiety w celu przeprowadzenia testów pilotażowych, podpięcia punktów z listy ministerialnej do czasopism ${ }^{11}$.

Działania nowego operatora systemu koncentrują się na doskonaleniu funkcjonalności, udostępnianiu nowych aplikacji, zgodnych z oczekiwaniami środowiska naukowego, które mają usprawnić proces przesyłania i wykorzystania raz zgromadzonych informacji. Umożliwi to:

— przeszukiwanie danych zgromadzonych w systemie według różnych kryteriów,

— podpięcie PBN do usług sieciowych Thomson Reuters, Web of Knowledge,

— rozwój PBN na potrzeby repozytorium publikacji w otwartym dostępie.

${ }^{10}$ PBN. Polska Bibliografia Naukowa, https://pbn-test.opi.org.pl/sedno-webapp/ [dostęp: 10.07. 2016].

${ }^{11}$ Szkolenie użytkowników. PBN. Polska Bibliografia Naukowa, http://pbn-pomoc.opi.org.pl/ index.php?option $=$ com_content \&view $=$ article\&id=132\&Itemid=215\&lang $=$ pl [dostęp: 12.07.2016]. 
Wprowadzone przez operatora nowe funkcjonalności w systemie oraz zapowiedź ich dalszego rozwoju dają nadzieję, że system zostanie dostosowany do oczekiwań użytkowników. W chwili obecnej system nie został w pełni dopracowany i nie odpowiada specyficznym potrzebom uczelni wyższych. System, który zmienia operatorów, nieustannie modyfikowany i udoskonalany, nie jest systemem przyjaznym dla użytkownika.

Działalność publikacyjna jednostek naukowych nie opiera się tylko na trzech typach publikacji wymienionych w rozporządzeniu. Specyficzny rodzaj publikacji mają np. uczelnie artystyczne, prawnicze, medyczne, którym trudno podporządkować się szablonowi typów dokumentów zastosowanemu w module sprawozdawczym. Jak takie jednostki naukowe mają kwalifikować publikacje pracowników naukowych?

Powodem obaw są nieprecyzyjne zapisy oraz ich różna interpretacja przez poszczególnych użytkowników, co przekłada się na jakość i poprawność wprowadzanych danych. Jeśli jeden algorytm przygotowany dla wszystkich będzie podstawą oceny parametrycznej jednostek, to dane muszą być spójne i czytelne dla wszystkich.

W praktyce biblioteki opracowują dane i prowadzą bazy publikacji pracowników w różnorodnych systemach informatycznych. Niewiele bibliotek pracuje w dedykowanym systemie, np. Expertus. Zdecydowana większość korzysta z własnych autorskich systemów, inne zdecydowały o wykorzystaniu funkcjonujących systemów bibliotecznych, dostosowując je do wymagań określonych w rozporządzeniu. Ta różnorodność programów przekłada się na jakość wprowadzanych danych i czasochłonność tego zadania.

Potwierdzeniem tej tezy są zaprezentowane systemy dokumentujące publikacje pracowników uczelni przez biblioteki o profilu rolniczo-przyrodniczym, które uczestniczyły w ogólnopolskim Seminarium Naukowym „ROL-BIB 2016”, zorganizowanym przez Bibliotekę Główną Uniwersytetu Przyrodniczego we Wroclawiu (BG UPWr) w dniach 2-3 czerwca 2016 r. ${ }^{12}$

Wiele bibliotek musiało dostosować swoje obecne systemy do wymagań sprawozdawczych modułu PBN-S - rozbudować pola do wprowadzania nowych danych bibliograficznych określonych w rozporządzeniu oraz napisać nowy program komputerowy do importu danych.

Należy zauważyć, że forma masowego importu danych do PBN-S odbywa się w ściśle określonym formacie. Aby dokonać importu, trzeba w pierwszej kolejności wyeksportować dane z bazy bibliograficznej (w systemie Aleph lub innym), a następnie dokonać konwersji danych do formatu wymaganego przez PBN-S i użyć tego programu do wyeksportowania opisów publikacji.

12 Ogólnopolskie Seminarium Naukowe Bibliotek Uczelni Wyższych o profilu rolniczo-przyrodniczym ,ROL-BIB 2016”, Pawtowice, 2-3 czerwca 2016 r. Prezentacje, http://www.bibl.up.wroc. $\mathrm{pl} /$ pdf/program_seminarium_naukowego_wroclaw_02-03.06.2016r.pdf [dostęp: 12.07.2016]. 
Do wprowadzenia tych zmian potrzebny był czas, ludzie i pieniądze. Wszystkie biblioteki poniosły koszty modyfikacji lub zakupu dodatkowych modułów. Wszystkie pokonały trudności związane z nowymi zadaniami i wywiązały się z obowiązków sprawozdawczych w terminie. Jednak praca na tzw. protezach do systemu jest bardzo pracochłonna i czasochłonna.

Przygotowując dane sprawozdawcze w tych systemach, trzeba wykonać wiele operacji typu import-eksport i wielokrotnie sprawdzać poprawność zaimportowanych danych.

Czy takie doświadczenia osób wprowadzających dane i wysyłających sprawozdania usprawiedliwiają pytanie o możliwość wprowadzenia jednego systemu informatycznego, zakupionego ze środków MNiSW dla wszystkich jednostek w kraju — może na wzór „licencji krajowej”?

Paradoksalnie, historia zatoczyła koło. W tym miejscu odwołam się do wniosków i wyzwań na przyszłość zawartych w referacie I. Sójkowskiej i B. Barańskiej-Malinowskiej nt. bibliografii publikacji pracowników w 2011 r. na konferencji „III Wrocławskie Spotkania Bibliotekarzy"13.

Postulaty zaprezentowane przez autorki referatu pięć lat temu są nadal aktualne i jak pokazuje praktyka, nadal potrzebne. Najważniejsze z nich dotyczyły:

— podjęcia działań w kierunku przekształcenia baz bibliograficznych w bazy bibliograficzno-abstraktowe z linkowaniem do pełnych tekstów artykułów z prenumerowanych czasopism elektronicznych, komercyjnych serwisów czasopism, wszystkich prac dostępnych w Internecie jako open access,

- zaprojektowania zintegrowanego przeszukiwania baz danych zgodnego z oczekiwaniami użytkowników,

— podjęcia starań wdrożenia wspólnego systemu bibliograficznego (z możliwością importowania i eksportowania opisów bibliograficznych do wspólnej bazy),

— określenia szczegółowych zasad dokumentowania dorobku naukowego (np. tryb zgłaszania, rodzaje prac, zasady ich kwalifikacji),

— dostosowania zawartości rekordów do wymogów analizy parametrycznej jednostek, wymagań MNiSW,

- uzupełniania opisów o wszystkie wymagane elementy niezbędne dla władz uczelni i wydziałów oraz analiz, zestawień statystycznych, rankingów itd.,

- wyboru koordynatora projektu oraz wspólnego systemu/programu do opracowania bibliograficznej bazy danych w kraju,

— opracowania szczegółowych zasad wprowadzania danych ${ }^{14}$.

${ }^{13}$ I. Sójkowska, B. Barańska-Malinowska, Bibliografia publikacji pracowników źródtem informacji wspomagającej przygotowanie oceny jednostek naukowych, [w:] Z problemów bibliotek naukowych Wrocławia, t. 10. III Wrocławskie Spotkania Bibliotekarzy, red. H. Szarski, D. Dudziak, Wrocław 2011, s. 17-31.

${ }^{14}$ I. Sójkowska, B. Barańska-Malinowska, Bibliografia publikacji pracowników źródłem informacji wspomagajacej przygotowanie oceny jednostek naukowych. Prezentacja, http://www. 
Założenia i postulaty były trafne. Z perspektywy czasu można uznać, że gdyby zostały zrealizowane i wdrożone, prawdopodobnie uniknęlibyśmy przynajmniej części obecnych kłopotów. To pokazuje również, jak bardzo świadome nadchodzących zmian były biblioteki już pięć lat temu.

System Informacji o Nauce, a zwłaszcza moduły PBN-R i PBN-S, powstał na potrzeby MNiSW. Dane gromadzone w systemie służą ściśle określonym zadaniom: publicznej dostępności podstaw do procesu ewaluacji jednostek oraz promocji nauki polskiej, jednak środowisko akademickie potrzebuje danych do celów wewnętrznych uczelni, do ocen, analiz, raportów.

Bibliograficzne bazy publikacji pracowników tworzone od dziesięcioleci przez bibliotekarzy spełniają i będą spełniały potrzeby oraz oczekiwania pracowników naukowych i władz uczelni. Ważne, aby wypracować takie narzędzia, taki model gromadzenia i wyszukiwania według różnych kryteriów, aby nadążyć za zmianami, które w istotny sposób będą kształtowały politykę działalności wydawniczej uczelni w najbliższych latach.

Bazy bibliograficzne publikacji pracowników są dla biblioteki podstawowym narzędziem wykonania oceny bibliometrycznej, sporządzania raportów, analiz czy zestawień dla władz uczelni, wydziału czy komisji. Prośby przesyłane do biblioteki dotyczą analizy publikacji pracowników w różnym ujęciu, nie tylko według wartości IF, liczby publikacji czy autorów publikacji. Obecnie konkurencyjność uczelni, wprowadzanie innowacji, wdrożeń, komercjalizacji, poszukiwanie źródeł finansowania wymuszają potrzebę głębokich analiz i porównań publikacji, pracowników, katedr, instytutów i wydziałów w różnych aspektach ich działalności wydawniczej.

Wyniki przygotowywanych przez biblioteki analiz są podstawą władz uczelni do oceny działalności publikacyjnej pracowników. Są wytyczną do wyróżniania, doceniania i nagradzania najbardziej aktywnych pracowników w zakresie publikacji oraz informacją o niskiej aktywności innych. Ocena i wnikliwa analiza danych może wskazać możliwości motywowania tej grupy pracowników do publikowania w renomowanych czasopismach naukowych posiadających IF.

Warto podkreślić, że jeszcze rok temu nie byłoby możliwe wykonanie analiz oraz raportów z wielu bibliotecznych baz publikacji. Główną przeszkodą była niekompletność bazy.

W funkcjonowaniu bibliotek dokonały się nieodwracalne zmiany. Uległa zmianie rola bibliotek i bibliotekarzy $\mathrm{w}$ dynamicznie rozwijającym się świecie oraz w związku z łatwym i wszechobecnym dostępem do elektronicznych źródeł informacji. Procesy gromadzenia, opracowania i udostępniania zbiorów biblioteki realizują łatwiej i szybciej. Do nich należy zakup książek, czasopism, zakup baz danych (konsorcja bibliotek), licencje krajowe, centralny system opracowywania

wsb.pwr.wroc.pl/Files/prv/id105/prezentacje/baranska-malinowska.barbara.sojkowska.iwona.pdf [dostęp: 12.07.2016]. 
zbiorów (katalog Nukat), spadek liczby użytkowników korzystających z klasycznej biblioteki, mniejsza liczba wypożyczonych zbiorów na rzecz e-wypożyczeń i wirtualnego korzystania z biblioteki i jej zasobów.

Czy zatem wdrożony i realizowany ogólnokrajowy System Informacji o Nauce jest szansą dla bibliotek akademickich?

Umiejętność i znajomość warsztatu bibliograficznego bibliotekarzy należy wykorzystać przy realizacji zadań w systemie POL-on. Nikt bowiem nie zna tak dobrze zasad opisów bibliograficznych i nikt nie zastąpi w tej roli bibliotekarzy. Biblioteki są przygotowane do tworzenia/współtworzenia systemów na poziomie lokalnym i krajowym, zarówno systemu informacji o nauce, jak i innych systemów zmierzających do gromadzenia metadanych. Raz zgromadzone dane według jednolitych standardów powinny być wykorzystywane do różnych celów i przez różnych odbiorców. Nowe zadania to także wyzwanie dla bibliotekarzy, którzy powinni nieustannie się dokształcać, zdobywać nowe umiejętności, stale się rozwijać, tworzyć zespoły zadaniowe.

Biblioteki otrzymały szansę i możliwość współpracy z jednostkami uczelni. W tym celu trzeba uczestniczyć w realizacji strategii uczelni:

- podejmować nowe wyzwania,

— być potrzebnym i widocznym w uczelni.

Najważniejsze cele uczelni w obecnej rzeczywistości to:

— dążyć do wysokiego poziomu naukowego i nauczania,

— prowadzić badania, być ekspertem w swojej dziedzinie,

— być liderem innowacji i transferu wiedzy,

— skomercjalizować wyniki badań,

— pozyskać granty, projekty,

— zwiększać wskaźniki widoczności naukowca/eksperta w kraju i na świecie,

— publikować z naukowcami w kraju i na świecie,

— współpracować z międzynarodowymi grupami badawczymi,

— publikować w renomowanych, wysoko punktowanych czasopismach,

— dążyć do osiągnięcia jak najwyższych wskaźników IF,

— dążyć do wzrostu liczby cytowań publikacji naukowców,

— zostać czołowym ośrodkiem w kraju w swojej dziedzinie,

— otrzymać najlepszą kategorię naukową,

— osiągać wysokie pozycje w rankingach,

— dobrze udokumentować swoją działalność w różnych systemach sprawozdawczych.

Po roku funkcjonowania systemu trzeba zadać pytanie: jakie zmiany w bibliotekach i uczelniach wymusił lub jakie problemy rozwiązał system POL-on?

Kwestią bezdyskusyjną jest rozwiązanie „odwiecznego” problemu systematycznego zgłaszania publikacji do biblioteki. Przez długie lata biblioteki nie mogły wyegzekwować tego obowiązku pomimo wydawanych i uaktualnianych zarządzeń rektora. Do tej pory w niektórych uczelniach pracownicy naukowi uważali 
za niepotrzebne apele bibliotek o cykliczne dostarczanie publikacji w celu dokumentowania ich w bazie.

System POL-on wymusił na pracownikach naukowych spełnianie tego obowiązku. Jedna ustawa rozwiązała problem wszystkich bibliotek. Biblioteki, które dotychczas miały kłopoty z bieżącym uzupełnianiem danych, stały się centralną, kompletną bazą danych publikacji pracowników uczelni. Tym samym biblioteka została partnerem uczelni, wiarygodnym źródłem informacji z kompleksową ofertą wyszukiwania, raportowania danych czy przygotowywania wykazów według różnych kryteriów zapytań dla: władz uczelni, naukowców, zespołów badawczych, komisji senackich, wnioskodawców do NCBiR i NCN, rankingów, nagród, awansów naukowych, konkursów na stanowiska, oceny okresowej pracowników $\mathrm{i}$ innych.

Nawiązała się ścisła współpraca biblioteki z koordynatorami wydziałowymi w zakresie merytorycznej oceny i kwalifikowania przygotowanych danych publikacyjnych do przekazania do systemu POL-on. Ta współpraca pozwoliła wydziałom dostrzec w bibliotekarzach partnerów do współpracy przy realizacji wspólnych celów.

POL-on, paradoksalnie, wpłynął również na kulisy bibliotekarskiej pracy, przez lata niedocenianej. Jednostki uczelni poznały ich zakres oraz uświadomiły sobie, jak obszerne i trudne są to zadania, wymagające od bibliotekarzy pewnych predyspozycji: cierpliwości i dociekliwości w poszukiwaniu źródeł opisów bibliograficznych, niezbędnych przy tworzeniu baz danych.

Cykliczne sprawozdawanie danych uporządkowało dane publikacji pracownika naukowego, jednostek naukowych, a tym samym całej uczelni.

POL-on wymusił także uporządkowanie i wdrożenie procedur związanych z obowiązkami sprawozdawczymi całej uczelni. Wydano stosowne zarządzenia określające strukturę uprawnień i odpowiedzialności. Powołano koordynatorów uczelni ds. POL-on z uprawnieniami do nadawania ról w systemie na różnych poziomach odpowiedzialności. Wyznaczono zakres zadań osobom wprowadzającym dane, nadzorującym jakość i poprawność wprowadzanych danych oraz osobom odpowiedzialnym za terminowe ich sprawozdawanie.

POL-on rozwiązał kwestię współpracy poszczególnych działów administracji uczelni, które sprawozdają dane o działalności uczelni do systemu.

Nieodzownym warunkiem właściwego wykorzystania danych raz wprowadzonych na uczelni jest kompatybilność systemów informatycznych pracujących w uczelnianej sieci. To zobowiązuje do ujednolicenia zasad wprowadzanych danych przez wszystkich współpracujących w systemie. Dostęp do danych (z określonymi uprawnieniami), ich powiązanie między systemami, z możliwością wykorzystania ich w sieci, ale również do sprawnego zidentyfikowania/potwierdzenia sprawozdawanych danych, nie powinno generować problemów.

Operator systemu OPI zapowiedział konieczność powiązania danych publikacji w PBN-S z indywidualnym numerem ID pracownika. Powiązanie bazy 
ID pracowników uczelni z biblioteczną bazą publikacji staje się koniecznością ze względu na obowiązek uzupełniania danych o afiliacji i zatrudnieniu autorów publikacji. Osoby wprowadzające opisy publikacji powinny mieć bezpośredni dostęp do tych danych. Analogiczna sytuacja dotyczy bazy doktorantów i emerytowanych pracowników, którzy nie są zatrudnieni, lecz afiliują publikację do tej uczelni. To są dane, które wymuszą konieczność kompatybilności systemów informatycznych. Raz wprowadzone dane kosztują i dlatego warto je dobrze wykorzystać.

To są najważniejsze dowody zmian, jakie dokonały się w czasie funkcjonowania systemu POL-on. Biblioteki coraz częściej wykonują zadania, których wyniki dla zarządzających uczelnią są jedynym wiarygodnym źródłem informacji, analizy, oceny czy raportu.

\section{Podsumowanie}

Doświadczenia związane z rocznym funkcjonowaniem systemu POL-on były i są trudne zarówno dla bibliotekarzy, jak i dla koordynatorów systemu oraz kierowników jednostek naukowych. Zobligowanie uczelni wyższych do sprawozdawania danych na zasadach określonych przez ministerstwo, niekonsultowanych ze społecznością akademicką, wprowadziło chaos i niezadowolenie. Uczelnie, w tym biblioteki, z trudem pokonały problemy natury merytorycznej, organizacyjnej, informatycznej czy braku zasobów ludzkich przy wywiązywaniu się z cyklicznych obowiązków sprawozdawczych.

Mimo licznych niedoskonałości należy obiektywnie uznać, że system POL-on wniósł na uczelnie niekwestionowane wartości wynikające z ustawowych obowiązków sprawozdawczych:

- uporządkował i spowodował wdrożenie procedur związanych z obowiązkami sprawozdawczymi uczelni wyższych,

— wprowadził jednolity sposób gromadzenia, przechowywania i udostępniania informacji o szkolnictwie wyższym w Polsce,

— utworzył bazę do oceny parametrycznej jednostek naukowych w kraju,

- udostępnił narzędzia do nowoczesnego zarządzania nauką oraz wspomagające podział dotacji statutowej,

- zgromadził i udostępnił w jednym centralnym miejscu informacje o czasopismach naukowych oraz publikacjach polskich naukowców,

- udostępnił publiczną bibliografię naukową osób i jednostek naukowych,

- umożliwił zapoznanie się z dorobkiem polskich naukowców, jednostek naukowych i uczelni,

— umożliwił złożenie ankiety czasopism naukowych (w czasie ich cyklicznych ewaluacji),

— umożliwił deponowanie pełnych tekstów publikacji w centralnym repozytorium PBN, 
— zintegrował dane z systemu z zasobami repozytoriów instytucjonalnych polskich uczelni i jednostek naukowych,

— wymusił wzrost świadomości i potrzebę kompletowania/systematycznego zgłaszania publikacji w uczelnianych bazach danych,

— wymusił nawiązanie ścisłej współpracy z wydziałami, wydziałowymi koordynatorami ds. publikacji i innymi jednostkami uczelni,

- wymusił uporządkowanie danych w jednostkach naukowych,

— wymusił jedną spójną ewidencję statystycznych danych w uczelniach,

— wymusił kompatybilność systemów i baz danych funkcjonujących w uczelniach.

System POL-on pozytywnie wpłynął na efekty współpracy bibliotek z jednostkami naukowymi uczelni. Biblioteki dostrzegły wartość i przydatność swoich działań, by:

— posiadać i zarządzać jedną bazą publikacji do sprawozdawczości, oceny pracowników, awansów, wniosków projektowych, grantów, promocji uczelni, rankingów,

- uczestniczyć w procesie gromadzenia danych do parametryzacji, dotacji jednostek naukowych,

— uczestniczyć w realizacji misji i strategii uczelni,

— uczestniczyć w tym, co jest ważne dla uczelni.

Wraz z wprowadzeniem obowiązku sprawozdawania danych do systemu POL-on biblioteki otrzymały niepowtarzalną szansę, aby realizować zadania przypisane bibliotekom i jednocześnie aktywnie współuczestniczyć w realizacji zadań uczelni jako ważny i nieodzowny partner. Partner poszukiwany, ceniony i doceniany przez władze uczelni, wydział, katedrę czy indywidualnego pracownika naukowego.

Czyżby nadszedł czas rzeczywistej realizacji hasła tygodnia bibliotek z 2015 r.: „WYBIERAM BIBLIOTEKĘ”?

\section{Bibliografia}

Funkcjonalności wdrożone. POL-on. Zintegrowany system o nauce i szkolnictwie wyższym, https:// polon.nauka.gov.pl/funkcjonalnosci-wdrozone1 [dostęp: 10.07.2016].

Komunikat w sprawie terminu wprowadzenia danych i informacji do systemu informacji o nauce w ramach Zintegrowanego Systemu Informacji o Nauce i Szkolnictwie Wyższym POL-on, http://www.nauka.gov.pl/g2/oryginal/2015_07/cd1bbba140db3271185d573b1009ec42.pdf [dostęp: 10.07.2016].

O nas. PBN. Polska Bibliografia Naukowa, https://pbn-test.opi.org.pl/sedno-webapp/ [dostęp: 10.07.2016].

O systemie. POL-on. Zintegrowany system o nauce i szkolnictwie wyższym, https://polon.nauka. gov.pl/system [dostęp: 2.07.2016]. 
Ogólnopolskie Seminarium Naukowe Bibliotek Uczelni Wyższych o profilu rolniczo-przyrodniczym „,ROL-BIB 2016”, Pawłowice, 2-3 czerwca 2016 r. Prezentacje, http://www.bibl.up.wroc. $\mathrm{pl} / \mathrm{pdf} /$ program_seminarium_naukowego_wroclaw_02-03.06.2016r.pdf [dostęp: 12.07.2016]. PBN. Polska Bibliografia Naukowa, https://pbn-test.opi.org.pl/sedno-webapp/ [dostęp: 10.07.2016]. Rozporządzenie Ministra Nauki i Szkolnictwa Wyższego z dnia 13 lipca 2012 r. w sprawie kryteriów i trybu wyznaczania kategorii naukowej jednostkom naukowym, Dz.U. 2012, poz. 877, http://isap.sejm.gov.pl/DetailsServlet?id=WDU20120000877 [dostęp: 10.07.2016].

Rozporządzenie Ministra Nauki i Szkolnictwa Wyższego z dnia 29 czerwca 2015 r. w sprawie Systemu Informacji o Nauce, Dz.U. 2015, poz. 944, http://isap.sejm.gov.pl/DetailsServlet?id=WDU20150000944 [dostęp: 10.07.2016].

Rozporządzenie Ministra Nauki i Szkolnictwa Wyższego z dnia 26 lutego 2016 r. zmieniające rozporządzenie w sprawie Systemu Informacji o Nauce, Dz.U. 2016, poz. 309, http://dziennikustaw.gov.pl/du/2016/309/1 [dostęp: 10.07.2016].

Sójkowska I., Barańska-Malinowska B., Bibliografia publikacji pracowników źródłem informacji wspomagającej przygotowanie oceny jednostek naukowych, [w:] Z problemów bibliotek naukowych Wrocławia, t. 10. III Wrocławskie Spotkania Bibliotekarzy, red. H. Szarski, D. Dudziak, Wrocław 2011, s. 17-31.

Sójkowska I., Barańska-Malinowska B., Bibliografia publikacji pracowników źródłem informacji wspomagajacej przygotowanie oceny jednostek naukowych. Prezentacja, http://www.wsb. pwr.wroc.pl/Files/prv/id105/prezentacje/baranska-malinowska.barbara.sojkowska.iwona.pdf [dostęp: 12.07.2016].

Szkolenie użytkowników. PBN. Polska Bibliografia Naukowa, http://pbn-pomoc.opi.org.pl/index. php?option=com_content\&view=article\&id=132\&Itemid=215\&lang=pl [dostęp: 12.07.2016].

Ustawa z dnia 15 stycznia 2015 r. o zmianie ustawy o zasadach finansowania nauki oraz niektórych innych ustaw nauki, Dz.U. 2015, poz. 249, http://www.dziennikustaw.gov.pl/DU/2015/249/1 [dostęp: 10.07.2016].

\title{
The influence of POL-on System on documenting academic achievements of university workers
}

\author{
Summary
}

Introduced in 2015 amended law on science financing regulations brought in big changes in higher education units. Universities and also academic libraries got new tasks. Legislators introduced in our country so called Science Information System under Integrated Information System regarding Science and Higher Education - POL-on. Academic units applying for statutory activity funds are obliged to send information related to their research and development activity to the System. One of the elements of POL-on System is Polska Bibliografia Naukowa PBN (Polish Scholarly Bibliography) in which we distinguish two modules - repository and reporting. Activity reports of higher education units will be sent to reporting module of PBN periodically. The system will collect information on research and development activity of the academic units and their effects, including publications and patents. Practically, the function of reporting the list of publications is realized by academic libraries in cooperation with scientific units. The paper discusses the most important assumptions of the System and its influence on documenting academic achievements realized by libraries.

It tries to analyze and evaluate previous experiences regarding this task. It is a voice in an ongoing discussion and tries to answer some of difficult questions like: 
— to what extend the introduced system meets the expectations of academic world?

- what kind of changes has the POL-on System forced in academic libraries and academic units?

- has the obligation of reporting publications had impact on libraries and academic units cooperation?

— would it be justified to introduce one computer system to develop and report publications of scientific units for reporting module of PBN?

KEYWORDS: Polish Scholarly Bibliography, Science Information System, POL-on, bibliography of publications, unit parameter evaluation, scientific publications. 